\title{
Millennium and Aventis in unique pact
}

On June 23, Millennium (Cambridge, MA) and Aventis Pharma, the pharmaceutical division of Aventis (Frankfurt, Germany), announced a "groundbreaking alliance" to develop and market drugs to treat inflammatory conditions. The $\$ 450$ million deal is the first biotech-pharma collaboration based on equal terms-Millennium has demanded a $50 \%$ share of the profits from future US drug sales, but will also contribute half of the drug development costs. As well as taking Millennium further towards becoming a biopharmaceutical company, the deal illustrates the increasing price tag on biotech intellectual property and the growing bargaining power of the biotech sector.

The agreement is complex and "not one deal, but several," according to Alan Crane, Millennium's vice president of corporate development. It comprises four elements: the joint development of technologies that will expedite drug discovery, an equity investment, technology transfer, and drug development. Millennium will receive a total of $\$ 450$ million: $\$ 250$ million will be invested in equity, giving Aventis a $2.5 \%$ stake in the company. Millennium will receive a further \$200 million in cash over the next 5 years in exchange for the non-exclusive transfer of its technologies such as sequencing, informatics, transcriptional profiling, and proteomics.

However, analysts are most excited about the drug development component of the deal. Aventis and Millennium will pool—and jointly develop and market - their early-stage compounds for treating specific inflammatory diseases including rheumatoid arthritis, asthma, chronic obstructive pulmonary disease, multiple sclerosis, and inflammatory bowel disease. Together these diseases form a potential multibillion dollar market. The alliance will concentrate on the development of small molecule drugs, but Millennium will retain the rights to develop antibody-based drugs and diagnostic products, whereas Aventis has rights to develop vaccines and products involving local administration of gene-based therapies.

The deal, says Daniel Mahony, a biotech analyst with ING Barings (New York), fits well with Millennium's aim of becoming a biopharmaceutical company that spans the whole gene-to-patient gamut. Taking its first major step towards this goal, Millennium, which started out as provider of gene-based discovery technologies to pharmaceutical partners, acquired neighboring biotech company

Liz Fletcher is a freelance writer working in Cambridge, UK.
LeukoSite (Cambridge, MA) last year (Nat. Biotechnol., 17, 1151). According to Mahony, LeukoSite grafted onto Millennium's discovery programme a portfolio of late-stage products, and skill and expertise in clinical development. The deal with Aventis, he says, is a logical next step: to strengthen its inflammation franchise, which currently comprises two drugs in phase II clinical trials: LDP-977, an asthma treatment, being co-developed with Taisho (Tokyo), and LDP-02, a treatment for inflammatory bowel disease, which is being co-developed with Genentech (San Francisco, CA).

Aventis is one of the most active companies in research in inflammation and has "one of the most interesting pipelines," according to Ted Tenthoff, biotech analyst with Robertson Stephens (New York). In addition, two of the key drivers of Aventis's sales growth are its antiinflammatory products Arava (leflunomide), for the treatment of rheumatoid arthritis, and Allegra (fexofenadine), for the treatment of allergic rhinitis. These generated $7 \%$ of sales (€ 836 million; $\$ 781$ million) for Aventis in 1999. However, Millennium, which still needs to build a sales force, stands to gain most from the transfer of sales know-how from Aventis, which has the sixth largest sales force in the US.

What's particularly unusual about this biotech-pharma deal is that Millennium has been able to negotiate such a large piece of the pie: it will split profits on US sales with Aventis, and receive undisclosed royalties on all sales outside the US, but will have to contribute $50 \%$ of all costs in order to do so. Fortunately, the four-pronged structure of the deal with Aventis will help Millennium alleviate the load in the near future, points out Alan Crane. "Income generated from the transfer of technology [component] will help

to offset the costs of clinical development."

Millennium has been able to strike such a deal thanks in part to the dire need of pharmaceutical companies for biotech intellectual property that can give them the edge in a highly competitive market. Eva Haas, biotech analyst at Old Mututal Securities (London) says the pharmaceutical industry is willing to pay a premium to biotech, but only in certain areas such as genomics and for novel drug targets

Millennium "has developed a gene-discovery engine that is second to none," says Tenthoff. Millennium has also excelled in its ability to integrate all the phases of drug development to help improve the success rate of getting drugs through the clinic. For this expertise, it has acquired a long list of pharma partners willing to pay a premium for its services; including the Aventis deal, the company has secured $\$ 1.8$ billion in research partnerships. Millennium doesn't have to make deals [to survive], says Mahony. "It can pick who it wants to work with and on what terms." For example, Millennium struck a five-year research deal worth $\$ 465$ million with Bayer in 1998 (Nat. Biotechnol., 16, 1005). And, in its licensing deal for LDP-977 with Taisho in January 2000, Millennium negotiated retention of the license for the product in the US, with Taisho also funding two-thirds of the development costs in the US and all of the costs outside of the US.

However, although Millennium's bargaining position is strong, becoming a biopharmaceutical company is expensive and risky. The cost of bringing a drug to market is estimated to be between $\$ 400$ million and $\$ 900$ million. Nevertheless, Mahony says that Millennium has to take this step if it "wants to grow from a $\$ 10$ billion business to a $\$ 100$ billion business." Liz Fletcher

\section{CD18 trials disappoint again}

Genentech (S. San Francisco, CA) has announced disappointing phase II trial results of its anti-CD18 monoclonal antibodies in treating heart attacks. Preliminary analysis of the data in June showed the antibody failed to meet its primary objective of improved coronary blood flow 90 minutes after treatment. Genentech is the fourth biotech company to run aground with $\mathrm{CD} 18$ as a target, but researchers and analysts say that rather than being the product of bad decisionmaking during clinical development, the failures represent the inherent risk of using animal models in research-a problem unlikely to be dispelled by advances in preclinical target screening.

CD18 is a key signaling receptor in lymphocyte adhesion-the process by which white blood cells leave the bloodstream and enter nearby tissues. The hope was that antiCD18 monoclonal antibodies would block the receptor, thereby reducing lymphocyte infiltration into inflamed tissue and decreasing tissue damage caused by the immune system during reperfusion injury when blood flow to an area is stopped, then re-started. Because this type of damage is common to both heart attacks and ischemic stroke-two of the leading causes of mortality in the industrialized 